\author{
Asian Journal of \\ Medical and Biological Research \\ ISSN 2411-4472 (Print) 2412-5571 (Online) \\ www.ebupress.com/journal/ajmbr
}

\title{
Article \\ Estimation of total methane emission from enteric fermentation of ruminant livestock in Bangladesh
}

S. A. Masudul Hoque ${ }^{1 *}$, Md. Mazharul Islam ${ }^{1}$, Abu Sadeque Md. Selim², Shabbir Ahmed ${ }^{3}$ and Md. Morshedur $\operatorname{Rahman}^{3}$

${ }^{1}$ Department of Animal Breeding and Genetics, Faculty of Veterinary Medicine and Animal Science, Bangabandhu Sheikh Mujibur Rahman Agricultural University, Gazipur-1706, Bangladesh

${ }^{2}$ Department of Animal Science and Nutrition, Faculty of Veterinary Medicine and Animal Science, Bangabandhu Sheikh Mujibur Rahman Agricultural University, Gazipur-1706, Bangladesh

${ }^{3}$ Department of Dairy and Poultry Science, Faculty of Veterinary Medicine and Animal Science, Bangabandhu Sheikh Mujibur Rahman Agricultural University, Gazipur-1706, Bangladesh

*Corresponding author: S. A. Masudul Hoque, Department of Animal Breeding and Genetics, Faculty of Veterinary Medicine and Animal Science, Bangabandhu Sheikh Mujibur Rahman Agricultural University, Gazipur-1706, Bangladesh. E-mail: mhoqueabg@bsmrau.edu.bd

Received: 07 June 2017/Accepted: 25 June 2017/ Published: 29 June 2017

\begin{abstract}
Ruminant livestock is one of the key elementsfor the agriculture-based economy of Bangladesh, although these animals are often condemned as a source greenhouse gas especially methane $\left(\mathrm{CH}_{4}\right)$.Total methane emission from the enteric fermentation of ruminants in Bangladesh considering Gazipur, Tangail and Mymensingh district is reflected in the output of the present study. The emission was measured using the dry matter intake (DMI) approach based on the total population of ruminants. Feed intake was recorded from onfarm observation and/or farmers records. It was observed that the ration supplied to bovines consisted of 50$60 \%$ green roughage, $31-41 \%$ rice straw, and $4-10 \%$ concentrate mixture. In terms of DMI rice straw has been contributed the highest (51-65\%) proportions followed by green forage (24-31\%) and concentrate mixture (717\%). In small ruminant ration, 90-95\% feed (DMI 75-86\%) was supplied from green grasses and remaining from concentrate mixtures. Although buffalo individually irrespective of sex and age emitted highest amount of methane followed crossbred and indigenous cattle, goat and sheep, the males produced a higher amount of methane than those of female in all species. Total methane emission in Gazipur, Tangail, and Mymensingh districts were $13359.15,13250.65$ and $13653.75 \mathrm{Kg} /$ day and $4876.11,4836.50$ and 4983.62 '000' $\mathrm{Kg} / \mathrm{year}$, respectively. In total $848,320 \mathrm{Kg} /$ day and 309,630 " $000 " \mathrm{Kg} / \mathrm{year}$ methane was measured to be emitted in Bangladesh by 56.33 million ruminant livestock where $64.79 \%$ had come from indigenous cattle followed by crossbreed cattle (20.82\%), Goat (8.79\%), Buffalo (5.17\%) and sheep (0.43\%).
\end{abstract}

Keywords: ruminant; methane (CH4); livestock; dry matter intake (DMI)

\section{Introduction}

Livestock is an integral part of agriculture and likely to be one of the most important instrumentsfor the economic growth and development of Bangladesh. There are about 23.27 million cattle (4.19 million crossbred and 19.08 million indigenous), 0.83 million buffaloes, 30.33 million goats and 1.90million sheep in Bangladesh which are essentially integrated with its agriculture as well as socioeconomic system (Banglapedia, 2014). The livestock sector contributes about $2.79 \%$ of total gross domestic products (GDP) which is almost $17.15 \%$ in total agricultural shares (Hoque et al., 2011; 2016). Nevertheless, about $44 \%$ of the total human consumable animal protein comes from livestock sources. Moreover, $4.31 \%$ of the total foreign currency comes from the export oflivestock originated processed leather and leather goods (Bostami et al., 2015). Besides the use of power 
tillers and tractors in crop cultivation, 30 percent of the total tillage is operated by livestock. Furthermore, about 20 percent of the total human population is directly and 50 percent is partially dependent on livestock sector (DLS, 2016). Despite the contribution, livestock, particularly the ruminants are one of the important sources of methane emission on a global scale. According to Singhal et al. (2005), the enteric fermentation of livestock contributes the highest proportion (59\%) of greenhouse gas (GHG) emitted from agriculture followed by rice cultivation (23\%), manure management (5\%), burning of agricultural crop residue (1\%) and soils (12\%). However, the anaerobic rumen acts as thestorehouse of feeds as well asa fermentation chamber in the ruminant stomach. Fermentation of carbohydrates generates free hydrogen, which is utilized by the methanogenic bacteria (like Methanobrevibacter ruminantium and Methanomicrobium mobile) in order to reduce carbon dioxide and emits methane (Singh and Mohini, 1999). The bacteria in the rumen and the methanogens with their symbiotic association increase the digestion and total microbial production. In general, about 8-12\%loss of total dietary energy occurs due to the formation of methane (Blaxter, 1965). Methane production in ruminants depends on the quality, quantity, and digestibility of feed as well as the type of animal concerned. They are capable of utilizing lower quality forages and crop residues, especially rice straw and weeds fromcropland. These lowquality feeds incur low digestibility and significantly contribute to producinghigh quantities of methane. Various attempts have been made to estimate the methane emission from livestock in India (Mohini and Singh, 2001; Garg and Shukla, 2002; Gupta, 2003), in Australia (Kurihara et al., 1999), in New Zealand (Lassey, 2007), USA (Johnson and Johnson, 1995) and so on. Although a study on estimation of greenhouse gas emission from the livestock sector of Bangladesh was conducted (Jahan and Azad, 2013), the contribution of ruminants to the total production of methane in Bangladesh is not measured completely. Therefore, it is important to focus on the emission of methane by enteric fermentation of the ruminants in Bangladesh. It is also important for the better management of agricultural inputs. Keeping the aforesaid reality in mind the present study was attempted to estimate the total methane emission from different categories of ruminant animals (Cattle, Buffalo, Goat, and Sheep) fed on different types of feeds in Gazipur, Mymensingh,Tangail District as well as Bangladesh.

\section{Materials and Methods}

The body weight, feed intake, DMI, and methane production of different animal are solely dependent on sex, age, breed, variety, feedstuffs, feeding management, etc. The feeding management and availability of feeds vary among different areas. Dairy animals are generally fed athigher plane of nutrition than non-dairy animals. Only $70 \%$ of the total population of young animals of cattle and buffaloes (in the age group of 0.5-1.0yr) was considered for methane emission, as methane is not produced in young calves (0-3months) due to the nonfunctioning other men. Kids and lambs (0-2 months old) were also taken as non-methane producing animals. However, the total population of other categories of livestock was taken for methane estimation.

\subsection{Identification and categorization of livestock species}

Different types of the animal were categorized according to species; age and type of productivity are summarized in the Table 1.

\subsection{Estimation of livestock population}

The total number of animals in the different category was recorded from the Upazila Livestock Officer (ULO) and District Livestock Officer's (DLO) office of the respective district. The livestock population of Bangladesh was cited from DLS official website (DLS, 2016), Banglapedia (2014) and Bangladesh Bureau of Statistics (BBS, 2013).

\subsection{Estimation of live weight}

Live weight of different categories of animals in the selected areas was estimated at farmer's house using Sheaffer's formula (Khan et al., 2003) as Live weight (lbs) $=\mathrm{G} 2 \times \mathrm{L} / 300$, where, $\mathrm{G}=$ Heart girth (inch) and $\mathrm{L}=$ length of animals (inch). The weight in lbs was converted into kg dividing by a factor 2.22.

\subsection{Estimation of dry matter intake (DMI)}

Feed intake in terms of $\mathrm{Kg} \mathrm{DMI} / \mathrm{head} /$ day was estimated. Initially, the fresh feed intake $(\mathrm{Kg})$ was estimated by surveying directly from farmer's house of selected areas. The DMI will be calculated using the data according to Ranjan (1997) and Jain et al. (1996) considering the DM (\%) of straw, green forage and concentrate mixture are 85,28 and 85 , respectively. 
2.5. Estimation of methane emission

Methane conversion factor recorded in numerous feeding experiments, conducted in different laboratories will be taken into consideration. The average value of methane conversion factor [in g CH4/(kg DMI/100 Kg live weight)] for a particular category of the animal was utilized for the calculation of total methane emission from that category of livestock. The methane emission factors (MCF) for all calves, bull calf, bull and bullock of crossbred cattle along with both male and female buffalo of different age categories (18.4) were taken from Srivastova and Gurg (2002). For heifer calf,milking cow and dry cow of crossbred cattle the MCF (19.26) was taken from Singh (1999). The MCF for all categories of indigenous cattle (16.60) and goat (18.00) were used from ATI (2000). For sheep, the MCF (13.04) was elucidated from Haque and Bhar (2001). Using the MCF for different categories of livestock, the $\mathrm{CH} 4$ emission (g CH4/Day and $\mathrm{Kg} \mathrm{CH} 4 /$ Year) was estimated.

\subsection{Data analysis}

The data generated from this experiment will be entered in Microsoft Excel worksheet, organized and processed for further analysis. The analysis was performed using statistical analysis system (SAS, 2010).

\section{Results and Discussion}

\subsection{Livestock population in selected districts and Bangladesh}

Data on the population of different categories of livestock collected from different sources were summarized in Table 2. It was observed that the total number of crossbred cattle, indigenous cattle, buffalo, goat and sheep in Gazipur district were 65984, 300473, 13071, 477638 and 29921, respectively; in Tangail district were 65449, 298032, 12965, 473759 and 29678, respectively; in Mymensingh district were 67439, 307098, 13359, 488170 and 30581, respectively. There is a total of 56.33 million ruminant livestock in Bangladesh which accounts for 19.08 million indigenous cattle, 4.19 million crossbreed cattle, 0.83 million Buffalo, 30.33 million Goat and 1.90 million sheep.

\subsection{Estimation of live weight and dry matter intake (DMI)}

Estimated live weight $(\mathrm{Kg})$ of different categories of animals is summarized in Table 3. The fresh feed intake and DMI are compiled in Figures 1 and 2. For estimating DMI the fresh feed intake (Kg) was measured by surveying directly from farmer's house. Here, emphasis will be given to the availability of feed rather than the requirement of the animals, as methane is produced from the feed consumed during the course of its digestion. It was observed that green forages comprise about 50-60\% of the total feed supplied to large bovines (cattle and buffalo) followed by rice straw (31-41\%) and concentrate mixture (4-10\%) (Figure 1). In terms of DMI, it was observed that rice straw contributedhighest amount (51-65\%) followed by green forage (24-31\%) and concentrate mixture (7-17\%) (Figure 2). In the case of goat and sheep, it was observed that about 90-95\% feed had come from green fodder and the remaining from concentrate mixture (Figure 1). In terms of DMI, green grasses contributed about $75-86 \%$ of total DMI (Figure 2). The results of some study on feed intake and DMI (Hossain et al., 2003; Baset et al., 2010) were also in accordance with our findings.

Table 1. Categorization of livestock species.

\begin{tabular}{llll}
\hline \multicolumn{2}{c}{ Cattle (Crossbred and indigenous) } & & Buffalo \\
Male & Female & Male & Female \\
\hline Calf $(<1.0 \mathrm{yr})$ & Calf $(<1.0 \mathrm{yr})$ & Calf $(<1.0 \mathrm{yr})$ & Heifer calves $(1-2 \mathrm{yrs})$ \\
Bull calves $(1-2 \mathrm{yrs})$ & Heifer calves $(1-2 \mathrm{yrs})$ & Bull calves $(1-2 \mathrm{yrs})$ & Milking cows \\
Breeding bull & Milking cows & Breeding bull & Dry cows \\
Bullocks & Dry cows & Bullocks & Sheep \\
& Goat & Male & Female \\
Male & Female & Lamb $(<1 \mathrm{yr})$ & Lamb $(<1 \mathrm{yr})$ \\
Kid $(<1 \mathrm{yr})$ & Kid $(<1 \mathrm{yr})$ & Ram $(1-3 \mathrm{yrs})$ & Ewe $(1-3 \mathrm{yrs})$ \\
Buck $(1-3 \mathrm{yrs})$ & Doe $(1-3 \mathrm{yrs})$ & & \\
\hline
\end{tabular}


Asian J. Med. Biol. Res. 2017, 3 (2)

Table 2. Livestock population of different categories in selected districts and Bangladesh.

\begin{tabular}{|c|c|c|c|c|c|c|}
\hline Species & Sex & Age/Type & $\begin{array}{l}\text { Bangladesh } \\
\text { (Million) }\end{array}$ & $\begin{array}{l}\text { Gazipur } \\
\text { (No.) }\end{array}$ & $\begin{array}{l}\text { Tangail } \\
\text { (No.) }\end{array}$ & $\begin{array}{l}\text { Mymensingh } \\
\text { (No.) }\end{array}$ \\
\hline \multirow{10}{*}{$\begin{array}{l}\text { Cattle } \\
\text { (Crossbred) }\end{array}$} & \multirow[t]{5}{*}{ Male } & Calf $(<1.0 \mathrm{yr})$ & 0.39 & 6142 & 6092 & 6277 \\
\hline & & Bull calves (1-2 yrs) & 0.34 & 5354 & 5311 & 5472 \\
\hline & & Breeding bull & 0.29 & 4567 & 4530 & 4668 \\
\hline & & Bullocks & 0.85 & 13386 & 13277 & 13681 \\
\hline & & Total & 1.87 & 29449 & 29210 & 30098 \\
\hline & \multirow[t]{5}{*}{ Female } & Calf $(<1.0 \mathrm{yr})$ & 0.41 & 6457 & 6404 & 6599 \\
\hline & & Heifer calves (1-2 yrs) & 0.37 & 5827 & 5779 & 5955 \\
\hline & & Milking cows & 0.81 & 12756 & 12652 & 13037 \\
\hline & & Dry cows & 0.73 & 11496 & 11403 & 11750 \\
\hline & & Total & 2.32 & 36535 & 36239 & 37341 \\
\hline \multirow{10}{*}{$\begin{array}{l}\text { Cattle } \\
\text { (Indigenous) }\end{array}$} & \multirow[t]{5}{*}{ Male } & Calf $(<1.0 \mathrm{yr})$ & 2.11 & 33228 & 32958 & 33961 \\
\hline & & Bull calves (1-2 yrs) & 1.6 & 25197 & 24992 & 25752 \\
\hline & & Breeding bull & 0.89 & 14016 & 13902 & 14325 \\
\hline & & Bullocks & 3.85 & 60630 & 60137 & 61967 \\
\hline & & Total & 8.45 & 133071 & 131990 & 136005 \\
\hline & \multirow[t]{5}{*}{ Female } & Calf $(<1.0 \mathrm{yr})$ & 2.18 & 34331 & 34052 & 35088 \\
\hline & & Heifer calves (1-2 yrs) & 1.74 & 27402 & 27179 & 28006 \\
\hline & & Milking cows & 4.32 & 68031 & 67479 & 69532 \\
\hline & & Dry cows & 2.39 & 37638 & 37332 & 38468 \\
\hline & & Total & 10.63 & 167402 & 166042 & 171093 \\
\hline \multirow[t]{10}{*}{ Buffalo } & \multirow[t]{5}{*}{ Male } & Calf (<1.0 yr) & 0.09 & 1417 & 1406 & 1449 \\
\hline & & Bull calves (1-2 yrs) & 0.07 & 1102 & 1093 & 1127 \\
\hline & & Breeding bull & 0.03 & 472 & 469 & 483 \\
\hline & & Bullocks & 0.05 & 787 & 781 & 805 \\
\hline & & Total & 0.24 & 3780 & 3749 & 3863 \\
\hline & \multirow[t]{5}{*}{ Female } & Calf $(<1.0 \mathrm{yr})$ & 0.11 & 1732 & 1718 & 1770 \\
\hline & & Heifer calves (1-2 yrs) & 0.09 & 1417 & 1406 & 1449 \\
\hline & & Milking cows & 0.21 & 3307 & 3280 & 3380 \\
\hline & & Dry cows & 0.18 & 2835 & 2812 & 2897 \\
\hline & & Total & 0.59 & 9291 & 9216 & 9496 \\
\hline \multirow[t]{8}{*}{ Goat } & \multirow[t]{4}{*}{ Male } & $\operatorname{Kid}(<1 \mathrm{yr})$ & 4.56 & 71811 & 71228 & 73394 \\
\hline & & Buck (1-2 yrs) & 3.57 & 56220 & 55764 & 57460 \\
\hline & & Buck (>2 yrs) & 4.03 & 63465 & 62949 & 64864 \\
\hline & & Total & 12.16 & 191496 & 189941 & 195719 \\
\hline & \multirow[t]{4}{*}{ Female } & Kid (<1 yr) & 4.86 & 76535 & 75914 & 78223 \\
\hline & & Doe (1-2 yrs) & 3.87 & 60945 & 60450 & 62289 \\
\hline & & Doe (>2 yrs) & 9.44 & 148661 & 147454 & 151939 \\
\hline & & Total & 18.17 & 286142 & 283818 & 292451 \\
\hline \multirow[t]{8}{*}{ Sheep } & \multirow[t]{4}{*}{ Male } & Lamb (<1 yr) & 0.31 & 4882 & 4842 & 4990 \\
\hline & & $\operatorname{Ram}(1-2$ yrs $)$ & 0.24 & 3780 & 3749 & 3863 \\
\hline & & $\operatorname{Ram}(>2$ yrs $)$ & 0.2 & 3150 & 3124 & 3219 \\
\hline & & Total & 0.75 & 11811 & 11715 & 12071 \\
\hline & \multirow[t]{4}{*}{ Female } & Lamb (<1 yr) & 0.29 & 4567 & 4530 & 4668 \\
\hline & & Ewe (1-2 yrs) & 0.25 & 3937 & 3905 & 4024 \\
\hline & & Ewe (>2 yrs) & 0.61 & 9606 & 9528 & 9818 \\
\hline & & Total & 1.15 & 18110 & 17963 & 18510 \\
\hline
\end{tabular}


Asian J. Med. Biol. Res. 2017, 3 (2)

Table 3. Live weight $(\mathrm{Kg})$ of different categories of animals

\begin{tabular}{|c|c|c|c|}
\hline Species & Sex & Age/Type & Lwt. (Kg) \\
\hline \multirow{8}{*}{ (Crossbred) } & Male & Calf $(<1.0 \mathrm{yr})$ & 70.54 \\
\hline & & Bull calves (1-2 yrs) & 151.62 \\
\hline & & Breeding bull & 270.41 \\
\hline & & Bullocks & 273.87 \\
\hline & Female & Calf $(<1.0 \mathrm{yr})$ & 74.90 \\
\hline & & Heifer calves (1-2 yrs) & 162.60 \\
\hline & & Milking cows & 296.70 \\
\hline & & Dry cows & 293.80 \\
\hline \multirow{8}{*}{$\begin{array}{l}\text { Cattle } \\
\text { (Indigenous) }\end{array}$} & Male & Calf $(<1.0 \mathrm{yr})$ & 61.22 \\
\hline & & Bull calves (1-2 yrs) & 132.45 \\
\hline & & Breeding bull & 259.87 \\
\hline & & Bullocks & 261.23 \\
\hline & Female & Calf $(<1.0 \mathrm{yr})$ & 60.23 \\
\hline & & Heifer calves (1-2 yrs) & 131.87 \\
\hline & & Milking cows & 203.45 \\
\hline & & Dry cows & 201.34 \\
\hline \multirow[t]{8}{*}{ Buffalo } & Male & Calf $(<1.0 \mathrm{yr})$ & 74.89 \\
\hline & & Bull calves (1-2 yrs) & 173.45 \\
\hline & & Breeding bull & 476.78 \\
\hline & & Bullocks & 475.67 \\
\hline & Female & Calf $(<1.0 \mathrm{yr})$ & 79.81 \\
\hline & & Heifer calves (1-2 yrs) & 175.34 \\
\hline & & Milking cows & 404.76 \\
\hline & & Dry cows & 398.54 \\
\hline \multirow[t]{6}{*}{ Goat } & Male & $\operatorname{Kid}(<1 \mathrm{yr})$ & 7.87 \\
\hline & & Buck (1-2 yrs) & 12.56 \\
\hline & & Buck (>2 yrs) & 19.24 \\
\hline & Female & $\operatorname{Kid}(<1 \mathrm{yr})$ & 7.69 \\
\hline & & Doe (1-2 yrs) & 13.98 \\
\hline & & Doe (>2 yrs) & 17.45 \\
\hline \multirow[t]{7}{*}{ Sheep } & Male & Lamb $(<1$ yr $)$ & 8.27 \\
\hline & & $\operatorname{Ram}(1-2$ yrs $)$ & 14.96 \\
\hline & & $\operatorname{Ram}(>2 \mathrm{yrs})$ & 21.59 \\
\hline & Female & Lamb (<1 yr) & 7.91 \\
\hline & & Ewe (1-2 yrs) & 13.51 \\
\hline & & Ewe (>2 yrs) & 18.93 \\
\hline & & Total & \\
\hline
\end{tabular}

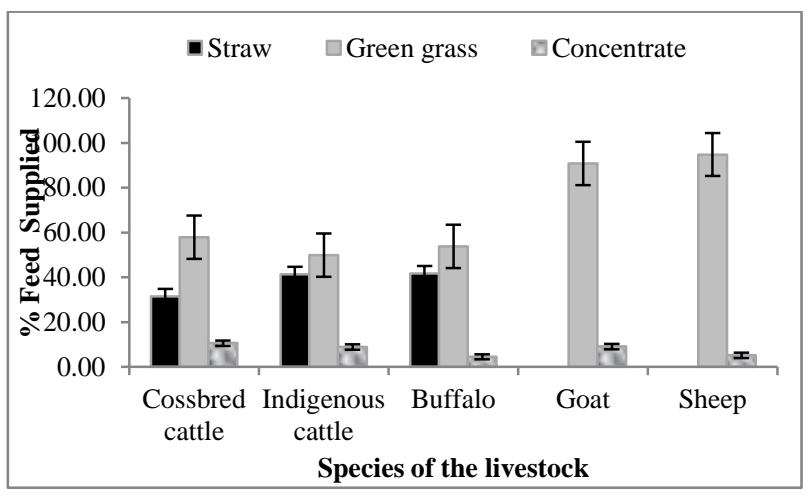

Figure 1. Fresh feed intake by different species of livestock. 


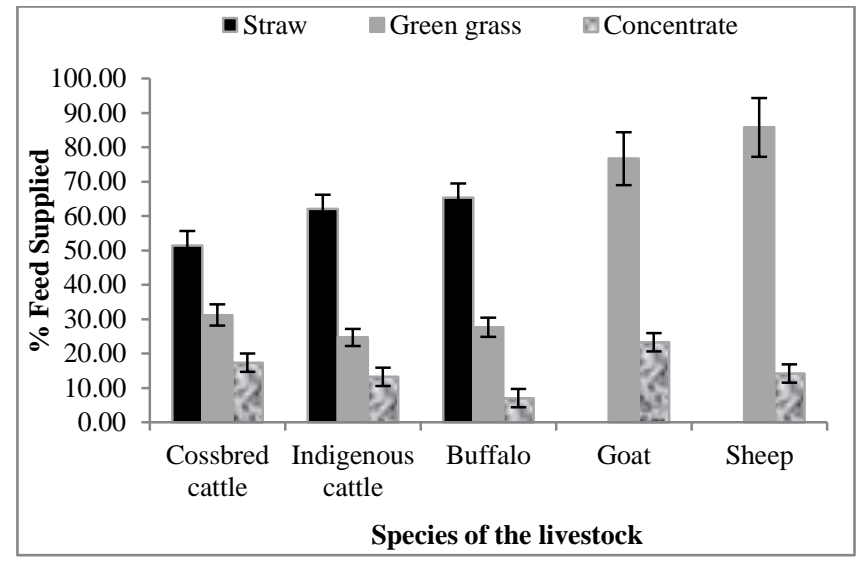

Figure 2. Dry matter intake (DMI) by different species of livestock.
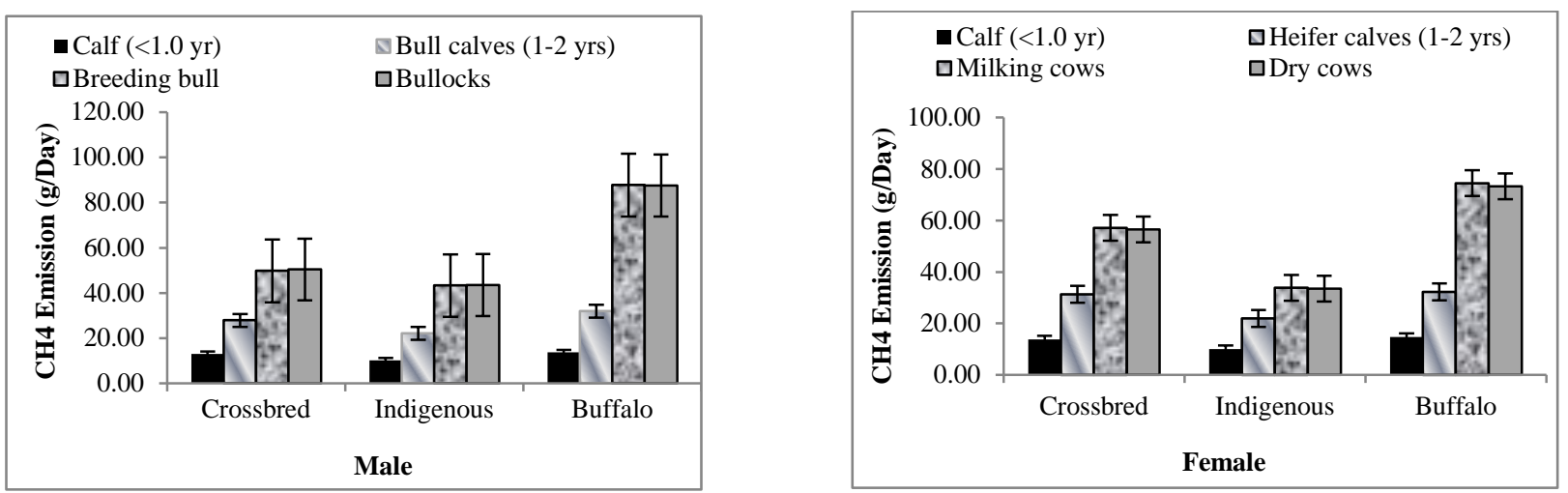

Figure 3 and 4. $\mathrm{CH}_{4}$ emission from male \& female Bovine (g/Day).
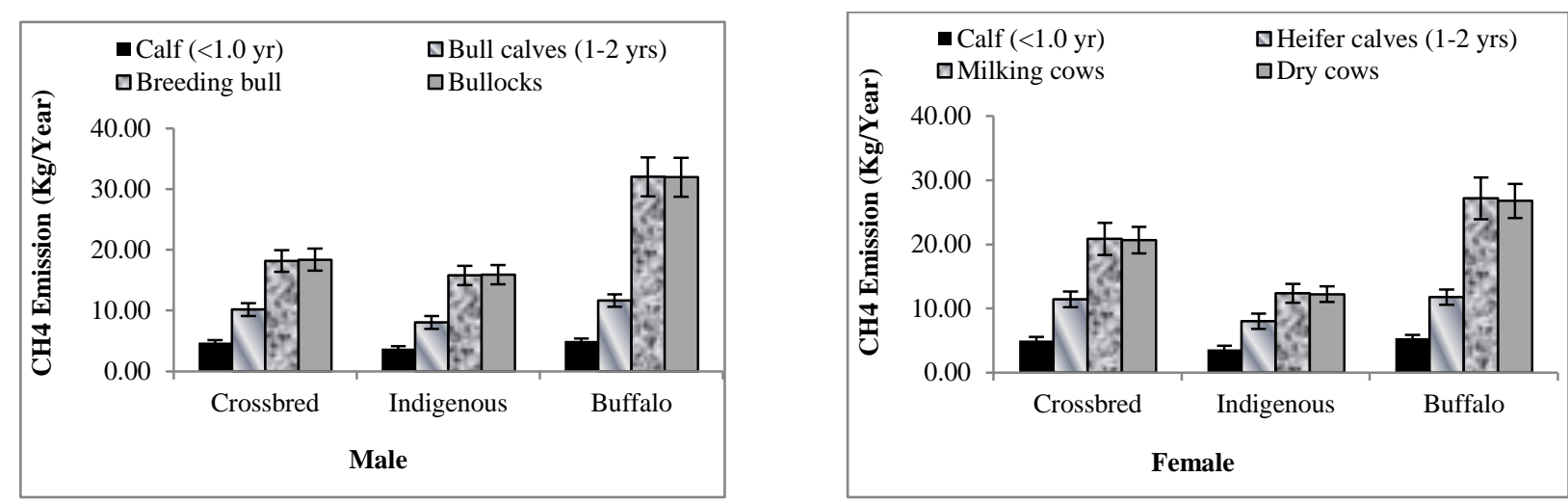

Figure 5 and 6. CH4 emission from male \& female Bovine (Kg/Year).
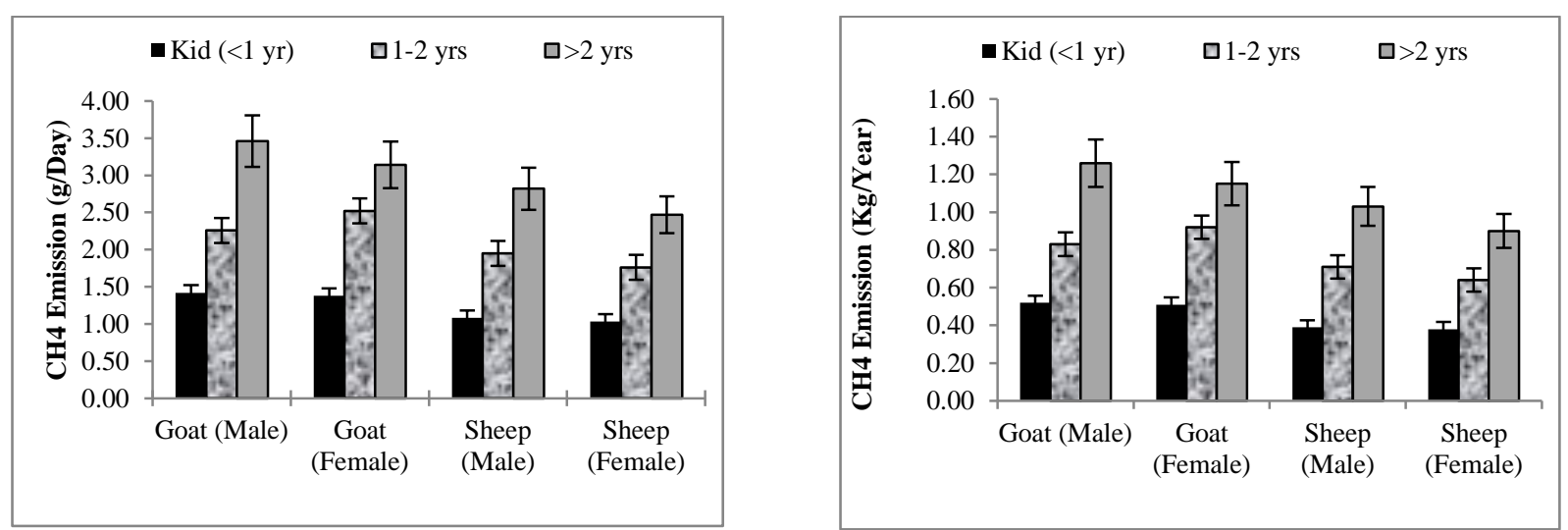

Figure 7 and 8. $\mathrm{CH}_{4}$ emission from goat and Sheep (g/Day) \& (Kg/Year). 


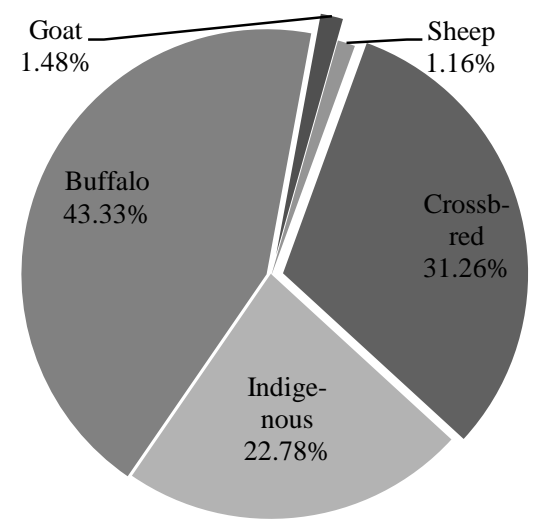

Figure 9. The total individual contribution of $\mathrm{CH}_{4}$ emission from Different species.

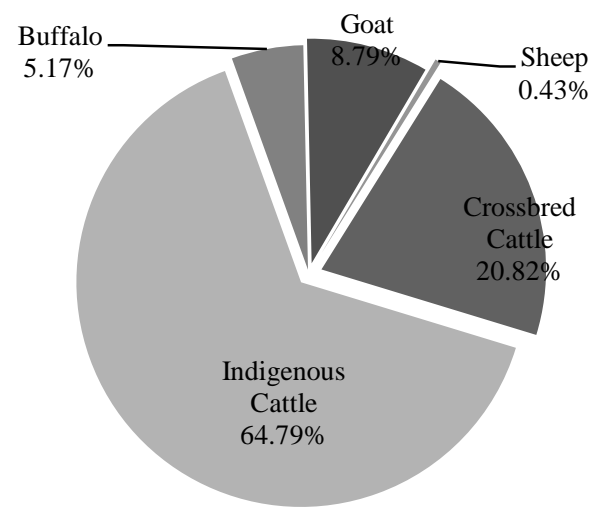

Figure 10. Total contribution of $\mathrm{CH}_{4}$ emission from Different species in Bangladesh.

\subsection{Estimation of methane emission}

The total methane emission estimated from each category of male and female bovine (Cattle and Buffalo) per day is shown in Figures 3 and 4, and per year in Figure 5 and Figure 6. Estimation of methane from sheep and goat are shown in Figure 7 (daily) and Figure 8 (yearly). The total contribution of methane emission from each species was summarized in Figure 9. Comparison between male and female, it was observed that males of all ruminant species studied here at irrespective of their age produced a higher amount of methane than those of females (Figures 3, 4, 5, 6, 7 and 8). Species wise partition revealed that a buffalo contributed the highest amount $(43.33 \%)$ followed by a crossbred cattle $(31.26 \%)$, an indigenous cattle $(22.78 \%)$, a goat $(1.48 \%)$ and a sheep (1.16\%) (Figure 9). In Bangladesh, only four types of livestock are responsible for the emission of $\mathrm{CH}_{4}$ by the enteric fermentation. In the previous study, Jahan and Azad (2013) stated that the major contribution of the emission occurs from cattle which were about $322.5 \times 10^{6} \mathrm{~g}$ in $1983-84$ and in $2008-09$ was about $344 \times 10^{6} \mathrm{~g}$. It is also mentioned in their study that the contribution ofagoatto $\mathrm{CH}_{4}$ emission is about $71 \times 10^{6} \mathrm{~g}$ in $1983-84$, $85.60 \times 10^{6} \mathrm{~g}$ in 1996 and $112 \times 10^{6} \mathrm{~g}$ in $2008-09$. It was measured that the total emission of methane $(\mathrm{Kg})$ per day in Gazipur, Tangail, and Mymensingh districts were 13359.15, 13250.65 and 13653.75, respectively, and (' 000 ' $\mathrm{Kg}$ ) per year were $4876.11,4836.50$ and 4983.62 , respectively. In the yearly methane production, the contribution of indigenous cattle is comparatively higher $(3,100,000$ to $3,350,000 \mathrm{Kg} / \mathrm{year})$, followed by crossbred cattle $(1,000,000$ to $1,050,000 \mathrm{Kg} /$ year), goat $(400,000$ to $440,000 \mathrm{Kg} /$ year), buffalo (250,000 to $260,000 \mathrm{Kg} /$ year) and sheep $(20,000$ to $22,000 \mathrm{Kg} /$ year). Considering the total ruminant population in Bangladesh, it was observed that total methane production in Bangladesh was $848,320 \mathrm{Kg} /$ day and 309,630,000 $\mathrm{Kg} /$ year from 56.33 million ruminant livestock. The earlier results of methane emission from enteric fermentation in Bangladesh observed by Jahan and Azad (2013) were $407.15 \times 10^{6} \mathrm{~g}$ in $1983-84,434.98 \times 10^{6} \mathrm{~g}$ in 1996 and $502.10 \times 10^{6} \mathrm{~g}$ in 2008-09. An increasing pattern of methane emission over time was observed in their study. The total emission of our study is somewhat lower than the previous study, which is might be due to improved animal nutrition for animal farming in recent years. The species wise contribution was summarized in Figure 10. Considering the species-wise methane emission it was observed that $64.79 \%(549,610 \mathrm{Kg} /$ day and $200,600,000 \mathrm{Kg} / \mathrm{year}$ ) of the total emission was contributed by 19.08 million indigenous cattle. The $2^{\text {nd }}$ highest emission $(20.82 \% ; 176,640 \mathrm{Kg} /$ day and $64,470,000 \mathrm{Kg} /$ year) occurred from 4.19 million crossbreed cattle. Goat population (30.33 million) of Bangladesh emitted $8.79 \%(74,610 \mathrm{Kg}$ /day and $27,230,000 \mathrm{Kg} /$ year) of total 
methane production. The contribution of Buffalo ( 0.83 million) and sheep (1.90 million) were 5.17\% $(43,840 \mathrm{Kg} /$ day and $16,010,000 \mathrm{Kg} /$ year $)$ and only $0.43 \%(3,620 \mathrm{Kg} /$ day and $1,320,000 \mathrm{Kg} /$ year $)$, respectively. This study is based on the developed methane conversion factors, but furthermore accurate study, we should validate the study with direct estimation method like $\mathrm{SF}_{6}$ Tracer Technique, Respiratory Chamber Techniques, Invitro Gas Production Technique and so on. However, the emission of methane gas from enteric fermentation in Bangladesh should be paid an attention formitigating. Methane is one of the major components ofgreenhouse gas like carbon dioxide $\left(\mathrm{CO}_{2}\right)$. The effect of $\mathrm{CH}_{4}$ is almost 23 times higher than those of the effect of $\mathrm{CO}_{2}$. Therefore, the emission of about $100 \mathrm{~kg}$ Methane per year for each cow is equivalent to about 2'300 $\mathrm{kg} \mathrm{CO}_{2}$ per year (Ogino et al., 2007). According to FAO (2013), agriculture is responsible for $18 \%$ of the total greenhouse gas emission of the world. Livestock is taking a major part of emission from agriculture. Almost $30 \%$ of the total land of the world's land surface is now engaged by livestock for farming, feed production etc. Now a day the human population in the world is increasing, the farming for supplying meat, milk and other animal products is also increasing. Hence the production of methane is increasing day by day. Therefore, we cannot disagree that livestock farming has a major impact on climate change and global warming. We have to find out the proper mitigation policy against the emission of methane from enteric fermentation. However, to validate our present study it is recommended to use some direct measurement techniques for measuring the emission of methane from enteric fermentation of livestock.

\section{Acknowledgements}

The authors would like to thank the Research Management Committee (RMC), Bangabandhu Sheikh Mujibur Rahman Agricultural University (BSMRAU), Gazipur-1706, Bangladesh for the financial support to conduct this piece of research. The corresponding author would like to acknowledge Professor Dr.M. Abdul Karim, Department of Agronomy and Professor Dr. Md. MizanurRahman, Department of Soil Science, BSMRAU, Gazipur-1706, Bangladesh for their valuable instructions, lessons, guidance and inspiration during preparing the research proposal.

\section{Conflict of interest}

None to declare.

\section{References}

ATI, 2000. Effect of molasses-urea product on productivity and methane reduction of buffalo, Kankrej and crossbred cattle in Gujarat State Report, Appropriate Technology India, Ahmedabad.

Banglapedia, 2014. http://www.banglapedia.org/HT/L_0133.htm

Baset MA, KS Huque, NR Sarker, MM Hossain and MN Islam, 2010. Evaluation of milk urea nitrogen of dairy cows reared under different feed bases in the different seasons. J. Sci. Foun., 8: 97-110.

BBS, 2013. Annual Report 2012-13, Bangladesh Bureau of Statistics, Parishankhyan Bhaban, E-27/A, Agargaon, Sher-e-Bangla Nagar, Dhaka-1207, Bangladesh.

Blaxter KL, 1965. The Energy metabolism of ruminants. Hutchinson and Co Ltd. London, U.K. 332

Bostami ABMR, ASM Selim, SAM Hoque, AKMZ Rabbi and MN Siddiqui, 2015. Effect of medicinal herb (Emblica officinalis) on growth performance, fecal microbiota and diarrhea prevalence in growing sheep. Int. J. Cur. Res., 7: 13720-13727.

DLS, 2016. Department of Livestock Service, Ministry of Fisheries and Livestock, Peoples' Republic of Bangladesh. Website: http://old.dls.gov.bd/Introduction.php

FAO, 2013. Statistical Yearbook 2013: World Food and Agriculture. Food and Agricultural Organisation, UN, Rome, Italy.

Garg A and PR Shukla, 2002. Emission inventory of India. Tata McGraw Hill Publishing Co Ltd., New Delhi. 84.

Gupta PK, 2003. Uncertainty reduction in methane and nitrous oxide emissions from livestock sector in India. Final report to Winrock International India, New Delhi.

Haque N and R Bhar, 2001. Effect of supplementation of mahua seed cake with or without bromochloromethane in the roughage-based diet on methane production in sheep. Proceedings of the Animal Nutrition Conference, Abstr.No. 255, NDRI, Karnal.

Hoque SAM, SK Kabiraj, MAMY Khandoker, A Mondal, and KMA Tareq, 2011. Effect of collection techniques on cumulus oocyte complexes (COCs) recovery, in vitro maturation and fertilization of goat oocytes. Afr. J. Biotech., 10: 9177-9181. 
Hoque SAM, MM Islam and ASM Selim, 2016. Interspecies differences on ovarian parameters between Black Bengal goat and indigenous Bengal sheep in view of in vitro maturation. Adv. Life Sci., 6: 54-60.

Hossain ME, M Shahjalal, MJ Khan and MS Hasanat, 2003. Effect of dietary energy supplementation on feed intake, growth and reproductive performance of goats under grazing condition. Pak. J. Nutr., 2: 159-163.

Jahan S and DAK Azad, 2015. Estimation of Green house gas emission from the livestock sector of Bangladesh. Int. J. Sci. Res., 4: 1148-1155.

Jain DK, KNS Sharma, TK Walli and SN Rai, 1996. Estimates of nutrients requirement and availability for the bovine population across major states in India. NDRI Publication, NDRI, Karnal. 281

Johnson KA and DE Johnson, 1995. Methane emission from cattle. J. Anim. Sci., 73: 2483-2492.

Khan H, S Zamin, MM Rind, R Rind and M Riaz, 2003. Use of Shaeffer's formula for the prediction of body weight of slaughtering cattle. J. Ani. Vet. Adv., 2: 176-178.

Kurihara M, T Magner, RA Hunter and GJ McCrabb, 1999. Methane production and energy partition of cattle in the tropics. Br. J. Nut., 81: 227-234.

Lassey KR, DC Lowe and AM Smith, 2007. The atmospheric cycling of radiomethane and the "fossil fraction" of the methane source, Atmos. Chem. Phys., 7: 2141-2149.

Mohini M and GP Singh, 2001. Methane production on maize-based ration in buffalo calves. Indian J. Anim. Nutr., 18: 204-209.

Ogino A, H Orito, K Shimada and H Hirooka, 2007. Evaluating environmental impacts of the Japanese beef cow-calf system by the life cycle assessment method. Ani. Sci. J., 78: 424-432.

Ranjhan SK, 1997. Proceedings of the national symposium on feeding strategies for eco-friendly animal production in India, IVRI, Izatnagar.65-75

SAS, 2010. SAS/STAT 9.3 User's Guide. SAS Institute Inc. Cary. NC.USA

Singh GP, 1998. Methanogenesis and production of greenhouse gases under animal husbandry system. Report of AP Cess Fund, National Dairy Research Institute, Karnal

Singh GP and M Mohini, 1999. The level of green maize affecting methane production on aroughage-based diet. Ind. J. Dai.Bio., 10: 14-19.

Singhal S, T Mathur, S Khan, DJ Upadhyay, S Chugh, R Gaind and A Rattan, 2005. Evaluation of methods for AmpC Beta-Lactamase in gram negative clinical isolates from Tertiary Care Hospitals. Ind. J. Med. Microb., 23: $120-124$.

Srivastava AK and MR Garg, 2002. Use of sulfur hexafluoride tracer technique for measurement of methane emission from ruminants. Ind. J. Dairy Sci., 55: 36-39. 